\title{
Effects of Climatic Conditions on Sap Flow in Sugar Maple
}

by

\author{
Y.T. Kim and R.H. Leech 1
}

\begin{abstract}
Temperature, sunlight and precipitation were studied to examine their influence on sugar maple (Acer saccharum Marsh) sap flow over a five-year period. Temperature was the most important climatic factor influencing the amount of sap flow. Sunlight also increased the sap flow, but rain one day before the sap collection reduced it.
\end{abstract}

\section{Résumé}

L'influence de la température, de l'ensoleillement et des précipitations sur la coulée de la sève a été étudiée sur l'érable à sucre (Acer saccharum March) pendant une période de cinq ans. La température était le facteur climatique qui influençait le plus la quantité de sève. L'ensoleillement augmentait aussi la coulée de sève cependant que la pluie, une journée avant la récolte de la sève, réduisait la coulée de celle-ci.

\section{Introduction}

Two groups of factors have been observed that influence the physical mechanism of sap flow in sugar maple (Acer saccharum Marsh): (1) the internal factors, including temperature and pressure within different parts of the tree (Clark 1874, Jones et al. 1903, Stevens et al. 1945, Marvin et al. 1951, 1956, Plamondon et al. 1980); and (2) external factors influencing the tree environment (Cool 1957, Plamondon 1977). None of these studies totally explains the mechanism of sap flow in sugar maple. In his studies of the external factors, Cool (1957) reported that sap flow was influenced only by maximum temperature, but Plamondon (1977) found that sap flow was affected by minimum temperature, differences between maximum and minimum temperatures, and global radiation.

To investigate these apparent contradictions, a study was made of the influence of climatic factors, such as temperature, sunshine, rain and snow on sugar maple sap flow over a five-year period.

The results of this study are intended to show maple sap producers the advantages of measuring meteorological conditions with simple instruments to guide their deployment of labor. When a lull in sap flow is predicted, the work force could be reduced and when a heavy flow is predicted it could be augmented.

Ministry of Natural Resources, Ontario Tree Improvement and Forest Biomass Institute, Maple, Ontario. LOJ 1 E0

\section{Materials and Methods}

The study area is located in the Greenlaw sugar maple woodlot $5 \mathrm{~km}$ south of Elmvale, Ontario, Canada $\left(44^{\circ} \mathrm{N}\right.$ latitude, $80^{\circ} \mathrm{W}$ longitude). The soil is a well drained gravelly sandy loam (Hoffman et al. 1962), on flat terrain $250 \mathrm{~m}$ above sea level.

The study was started in 1977. Forty-five mature sugar maples were selected in a mature (about 100 years old) sugar maple woodlot having minor components of yellow birch (Betula alleghaniensis Britton), American beech (Fagus gradifolia Ehrh.), and immature sugar maple. Diameters of selected trees (measured at $1.3 \mathrm{~m}$ height) ranged from 27.5 to $51.3 \mathrm{~cm}$, and tree heights ranged from 24.5 to $33.8 \mathrm{~m}$.

Field observations were made during March and April of 1977 to 1981 . Each year, one taphole was drilled per tree at $1.3 \mathrm{~m}$ and the sap was collected at 8:00 a.m. (night flow) and 4:30 p.m. (day flow), from an aluminum bucket hung on a commercial spile and connected to an overflow bucket on the ground. Buckets were tightly covered with lids to prevent entry of rain and snow. The air temperature was read at the time of sap collection from two maximum and minimum thermometers, at north and south observation points in the woodlot about $100 \mathrm{~m}$ apart to average readings over an experimental area of about 1 ha. Sap sugar concentrations were measured in an on-site trailer after 4:30 p.m. daily by averaging two sample readings of a Fisher hand refractometer fitted with a compensating thermometer. The data on rain and snow were 


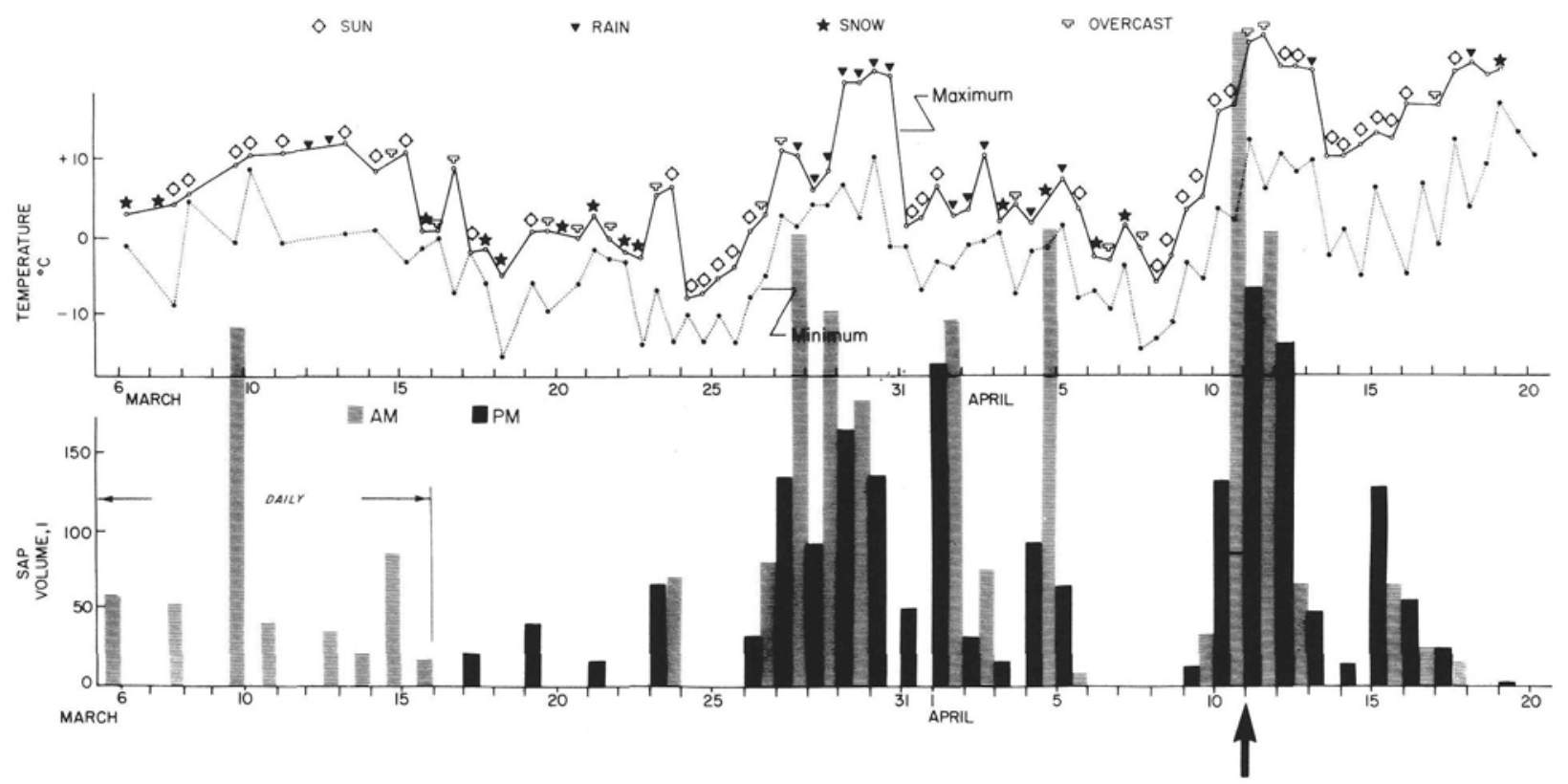

Figure 1. Sugar maple sap flow and weather for 1977. $\uparrow$ : the highest flow day (AM+PM) in the season. (Only a single measurement was made daily between March 6 and 16.) Each date shown on the abscissa represents the midpoint between two daily measurements.

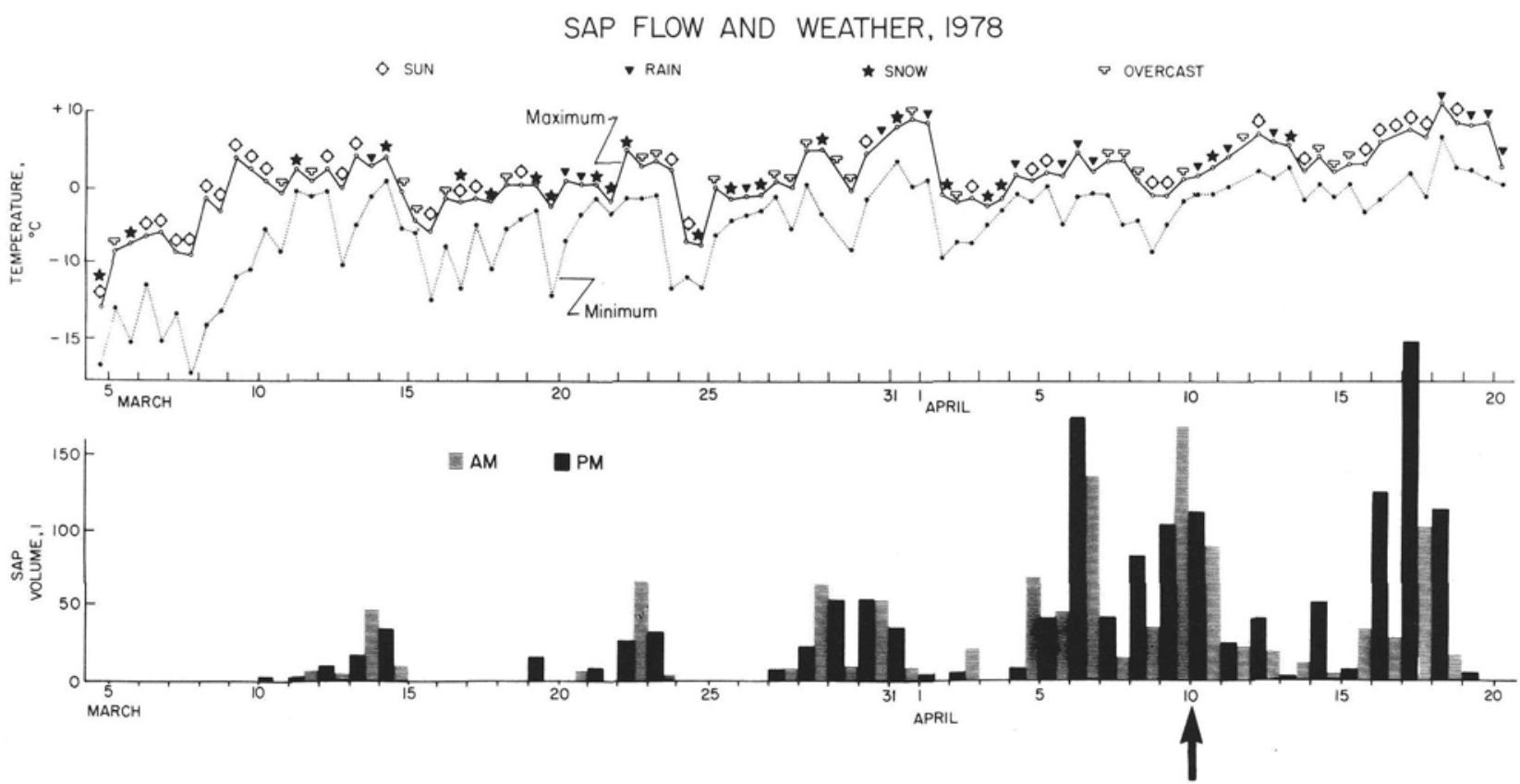

Figure 2. Sugar maple sap flow and weather for 1978. $\uparrow$ : the highest flow day $(A M+P M)$ in the season. Each date shown on the abscissa represents the midpoint between two daily measurements. 


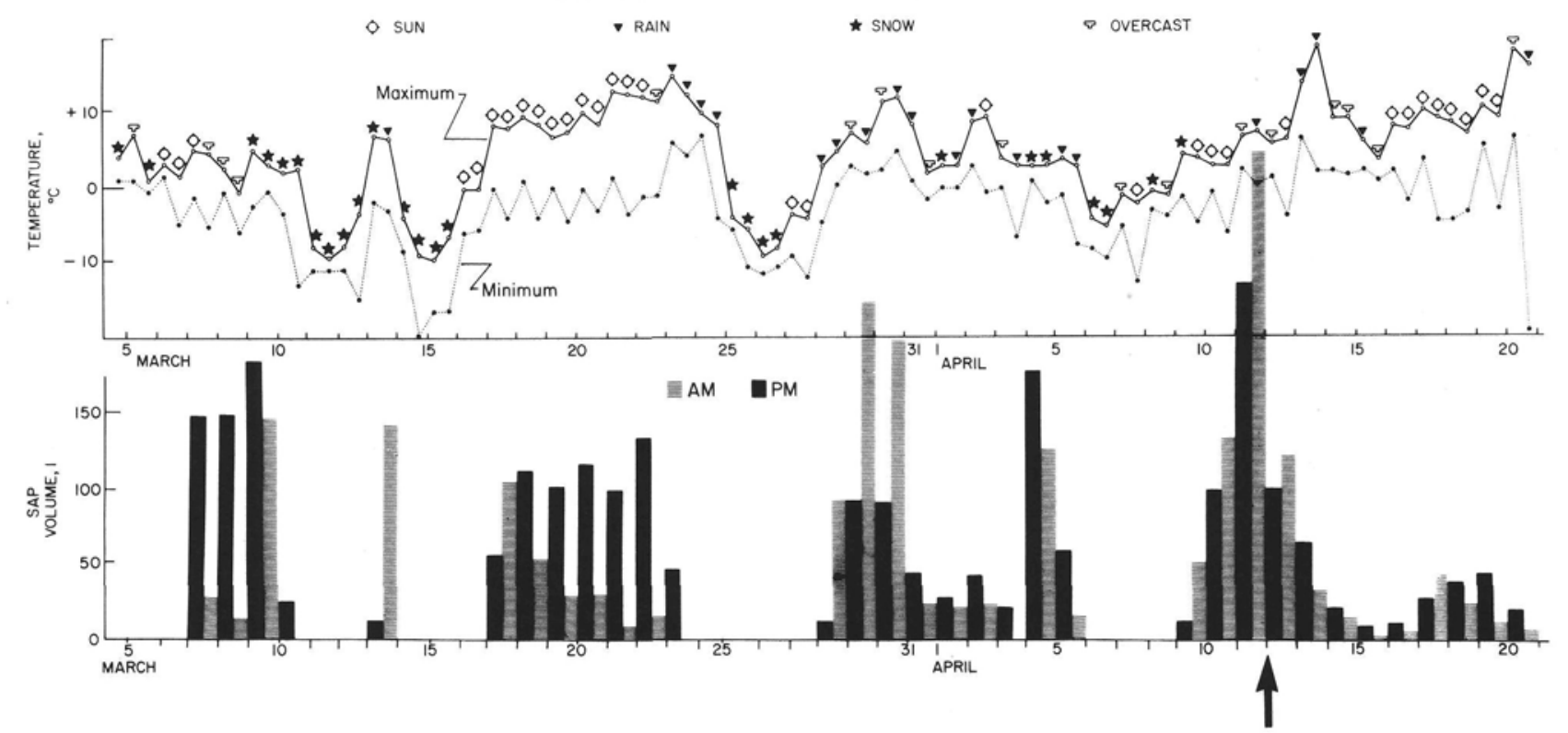

Figure 3. Sugar maple sap flow and weather for $1979 . \uparrow$ : the highest flow day (AM+PM) in the season. Each date shown on the abscissa represents the midpoint between two daily measurements.

SAP FLOW AND WEATHER, 1980

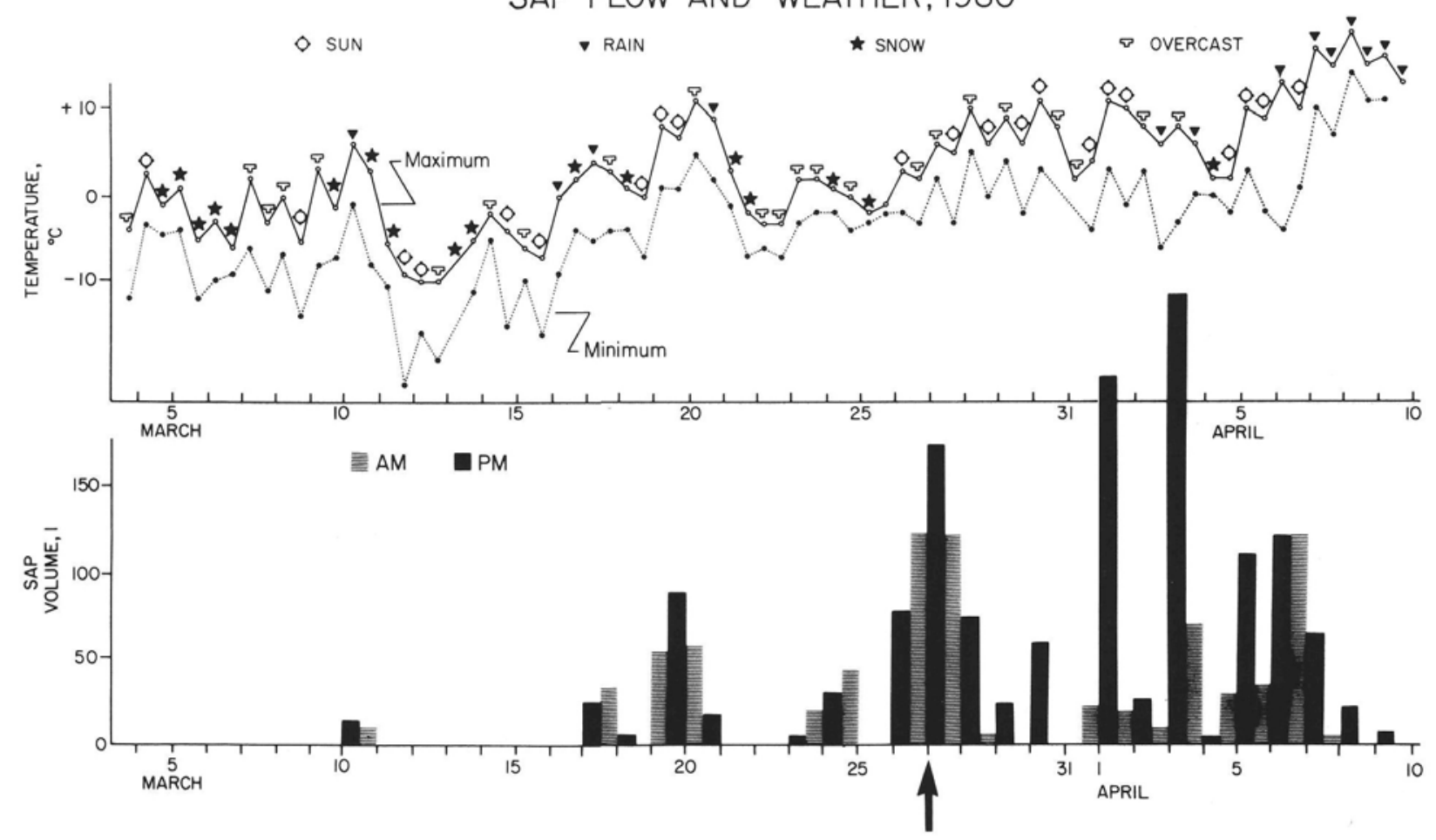

Figure 4. Sugar maple sap flow and weather for $1980 . \uparrow$ : the highest flow day (AM+PM) in the season. Each date shown on the abscissa represents the midpoint between two daily measurements. 


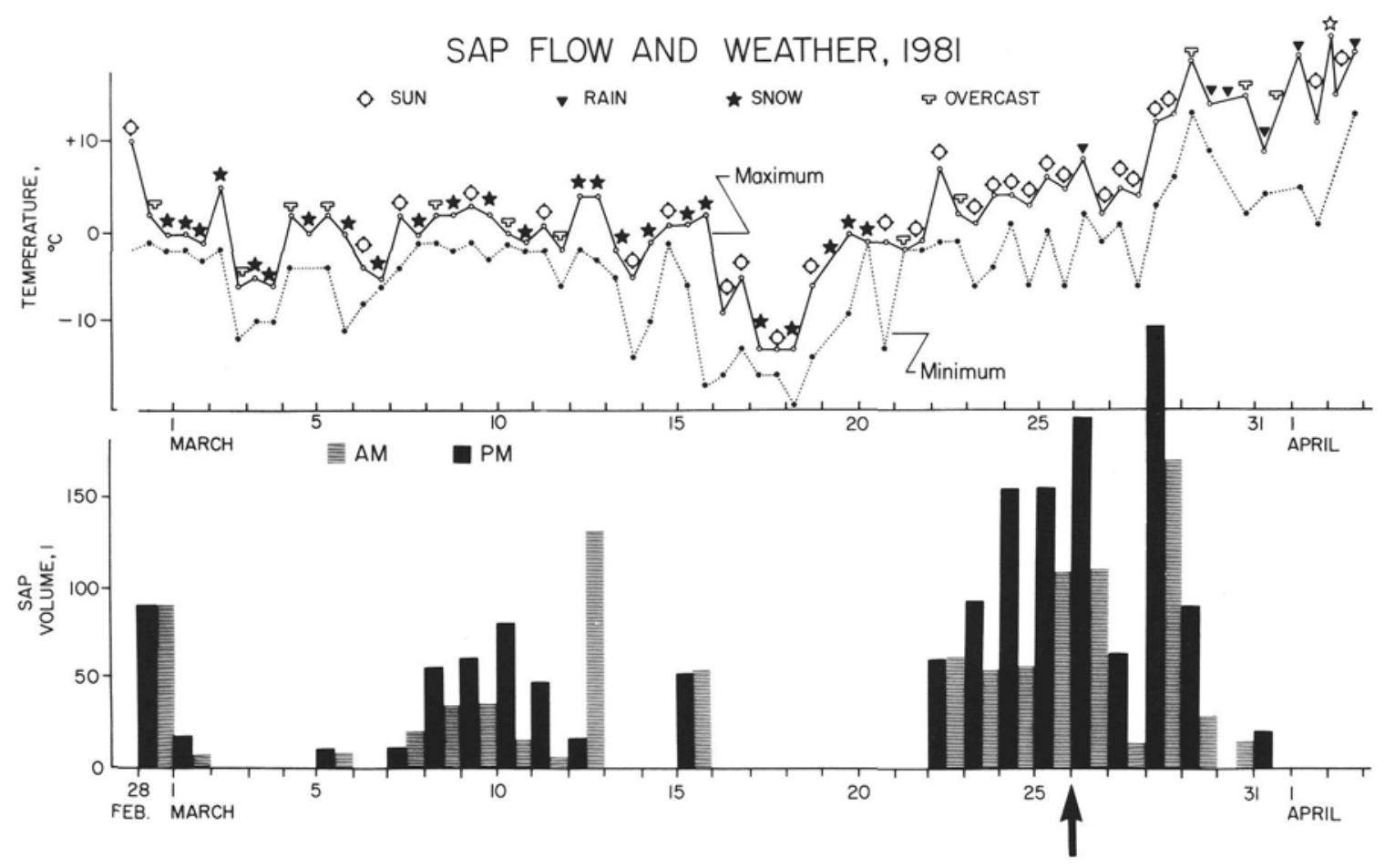

Figure 5. Sugar maple sap flow and weather for 1981. $\uparrow$ : the highest flow day $(A M+P M)$ in the season. Each date shown on the abscissa represents the midpoint between two daily measurements.

obtained from the Midhurst meteorological station maintained by Environment Canada, $9 \mathrm{~km}$ from the woodlot. The amount of overcast was observed at the woodlot at the time of sampling. The sap flow for a sunny day was calculated from the daytime flow only between 8:00 a.m. and 4:30 p.m., i.e. excluding night flow. This was compared with cloudy day flow, including flows on rainy, snowy and overcast days, which were also recorded in the field.

Stepwise regression and simple correlation coefficients were calculated on five-year measurements to determine which weather factors contributed significantly to sap flow.

\section{Results and Discussion}

Data on weather conditions and sap flow during March and April of the five consecutive years are given in Fig. 1-5.

Maximum temperature was the most important climatic factor to increase sugar maple sap flow over the five years (Table 3), although there were also significant relations between minimum temperature and sap flow in 1978 and 1979, apparently because April was colder in these two years than in the other three years. This differs from Plamondon's (1977) findings that the daily minimum temperature and the difference between the maximum and minimum temperatures were correlated with sap flow in a one-year experiment in Quebec. Cool (1957) on the other hand, in a four-year experiment in central Mighigan, found that daily maximum temperature was the only climatic factor that correlated significantly with sap flow.

As the maximum temperature decreased, the sap flow lessened and then stopped usually below $-4^{\circ} \mathrm{C}$ although sometimes it stopped above the freezing point (Fig. 1-5).
Jones et al. (1903) and Marvin et al. (1956) noted that sap flow is controlled mainly by xylem temperature which does not reach the freezing point until the air temperature drops below $-3^{\circ} \mathrm{C}$. In our study, the maximum air temperatures which coincided with the greatest sap flow ranged widely from 5 to $26^{\circ} \mathrm{C}$, and the minimum temperatures from -4 to $7^{\circ} \mathrm{C}$ (Fig. 1-5).

Sunshine is the next important weather factor influencing sap flow. Day and night flow varied seemingly unexplainably in the Greenlaw woodlot. Night flow sometimes exceeded day flow (Table 1 and Fig. 1-5), possibly when the average night temperature exceeded the day temperature, although this was not confirmed by measurement since only maximum and minimum night temperatures were recorded. Over the fiveyear period, the daytime flows were $43 \%$ greater on sunny than on cloudy days (Table 2); but the difference was less variable than that shown by Plamondon (1977) who found that the sunny day flow was 8 to 9 times greater than the cloudy day flow. Cool (1975) indicated that the sap flow was not closely related to percentage sunshine, but he did find some significant increase in sap flow after the trees had been warmed by direct sunlight.

The average sap flow during rainy days was greater than the average of the daily flow under all conditions (Table 2). Over a five-year period, the highest flow occurred on a rainy day in 1978, 1979 and 1981, (Fig. 2, 3 and 5). On two of these days, it rained only in the afternoon. The amount of rain had no significant effect on the sap flow on the day of collection (Table 3). However, the amount of rain one day before sap collection was negatively correlated with sap flow. Neither the amount of snow nor the days of snowfall affected sap flow (Table 3). The decline in sap flow after rain and snow was a result of the accompanying drop in air temperature. On the whole, temperature played the most important role in the sap 
Table 1. Sap flow and prevailing weather during sap collection season from 1977 to 1981 in Greenlaw woodlot.

\begin{tabular}{|c|c|c|c|c|c|c|c|c|}
\hline Year & $\begin{array}{c}\text { Collection } \\
\text { period }\end{array}$ & Time & $\begin{array}{c}\text { Total sap } \\
\text { volume }\end{array}$ & $\begin{array}{l}\text { Total } \\
\text { sugar }\end{array}$ & Tmax & Tmin & Rain* & Snow \\
\hline & & & $\mathbf{L}$ & kg & ${ }^{\circ} \mathrm{C}$ & ${ }^{\circ} \mathrm{C}$ & $\mathbf{m m}$ & $\mathbf{c m}$ \\
\hline \multirow[t]{2}{*}{1977} & Mar. 17-Apr. 19 & $\begin{array}{l}\mathrm{N}^{1} \\
\mathrm{D}\end{array}$ & $\begin{array}{l}2729.7 \\
2283.7 \\
\end{array}$ & $\begin{array}{l}47.5 \\
41.5 \\
\end{array}$ & $\begin{array}{l}7.5 \\
8.4\end{array}$ & $\begin{array}{r}-3.8 \\
1.3\end{array}$ & & \\
\hline & & Total & 5013.4 & 89.0 & & & 3.5 & 18.1 \\
\hline \multirow[t]{2}{*}{1978} & Mar. 9-Apr. 20 & $\begin{array}{l}\mathrm{N} \\
\mathrm{D}\end{array}$ & $\begin{array}{l}1092.9 \\
1485.9 \\
\end{array}$ & $\begin{array}{l}22.5 \\
31.7 \\
\end{array}$ & $\begin{array}{r}-0.5 \\
1.0\end{array}$ & $\begin{array}{l}-8.1 \\
-4.2\end{array}$ & & \\
\hline & & Total & 2578.8 & 54.2 & & & 54.2 & 9.1 \\
\hline \multirow[t]{2}{*}{1979} & Mar. 4-Apr. 20 & $\begin{array}{l}\mathrm{N} \\
\mathrm{D}\end{array}$ & $\begin{array}{l}2017.3 \\
2442.5 \\
\end{array}$ & $\begin{array}{l}41.4 \\
47.8 \\
\end{array}$ & $\begin{array}{l}3.8 \\
4.8\end{array}$ & $\begin{array}{l}-4.3 \\
-1.0\end{array}$ & & \\
\hline & & Total & 4559.8 & 89.2 & & & 56.4 & 38.0 \\
\hline \multirow[t]{2}{*}{1980} & Mar. 4-Apr. 9 & $\begin{array}{l}\mathrm{N} \\
\mathrm{D}\end{array}$ & $\begin{array}{r}680.1 \\
1463.5 \\
\end{array}$ & $\begin{array}{l}13.2 \\
29.4 \\
\end{array}$ & $\begin{array}{l}1.7 \\
4.5\end{array}$ & $\begin{array}{l}-5.3 \\
-1.2\end{array}$ & & \\
\hline & & Total & 2143.6 & 42.6 & & & 63.4 & 23.0 \\
\hline \multirow[t]{2}{*}{1981} & Mar. 1-Apr. 3 & $\begin{array}{l}N \\
D\end{array}$ & $\begin{array}{l}1365.9 \\
1708.6 \\
\end{array}$ & $\begin{array}{l}34.0 \\
46.0 \\
\end{array}$ & $\begin{array}{l}1.5 \\
2.1\end{array}$ & $\begin{array}{l}-5.0 \\
-2.0\end{array}$ & & \\
\hline & & Total & 3074.5 & 80.0 & & & 31.6 & 10.6 \\
\hline
\end{tabular}

$1 \mathrm{~N}=$ Daily measurement at 8:00 a.m. (night flow)

$\mathrm{D}=$ Daily measurement at 4:30 p.m. (day flow)

Measurements were made everyday during the collection period

-Rain and snow were from the Midhurst meteorological station.

Table 2. Sugar maple sap flow and weather, 1977-81.

\begin{tabular}{lc}
\hline Weather condition & $\begin{array}{c}\text { Mean sap flow for } \mathbf{5} \text { years, } \\
\text { L/day }\end{array}$ \\
\hline Sunny days (daytime only) & 55.3 \\
Cloudy days (daytime only) & 39.0 \\
Rainy days & 105.3 \\
One day before rain & 140.2 \\
One day after rain & 85.7 \\
Snowy days & 48.6 \\
One day before snow & 48.8 \\
One day after snow & 30.2 \\
Daily flow & 84.7 \\
\hline
\end{tabular}

Table 3. Tests of significance by stepwise regression and simple correlation coefficient between sap flow of sugar maple and related weather factors in the Greenlaw woodlot, 1977-81.

\begin{tabular}{|c|c|c|}
\hline $\begin{array}{l}\text { Weather } \\
\text { factors }\end{array}$ & $\begin{array}{l}\text { Day of sap } \\
\text { collection }\end{array}$ & $\begin{array}{l}\text { One day before } \\
\text { sap collection }\end{array}$ \\
\hline$T \max { }^{1}$ & ** & * \\
\hline $\operatorname{Tmin}{ }^{1}$ & NS & NS \\
\hline Tmax-Tmin 1 & NS & NS \\
\hline Rain² & NS & $(-)^{\star}$ \\
\hline Snow ${ }^{2}$ & NS & NS \\
\hline
\end{tabular}

$\because$ significant at .05 and .01 levels, respectively

NS not significant

test by stepwise regression

2test by simple correlation coefficien

$(-)$ negative relationship.

flow and good sap flow occurred with extreme fluctuations in temperature such as when a warming trend preceded rain.

\section{Application}

The technology of collecting and processing maple sap has improved greatly in recent years but without an associated improvement in silvicultural treatments of sugar maple woodlots to increase sap production and sugar concentration. The simple monitoring of temperature as recommended in this paper is not a common practice, although it could save the maple sap operators time and money by allowing them to reduce labour in collecting sap. This study is one of three carried out on the same area. One study was intended to show the relation of nutrition to sap flow, and second to show the relation between crown development, nutrition and sap flow. The present study was intended to show the relation between climatic factors and sap flow. The results of these studies probably should be applied in reverse order. If operators can be shown the advantage of temperature measurements to reduce sap collection costs, they may then be ready to adopt other simple procedures to the same end, such as the thinning of immature overstocked stands, not only to remove diseased trees, but also to create symmetrical crowns on residual trees. This could reduce the loss of sugar production caused by the splitting off of asymmetrical crown branches in older trees which is a common phenomenon at present.

\section{Acknowledgements}

We express our gratitude to D. Maclver for advice with statistical analysis and to Ms. D. Cermak for computer assistance.

\section{References}

Clark, W.S. 1874. The circulation of sap in plants. Mass. Board of Agric., 21st Ann. Report: 159-205.

Cool, B.M. 1957. An investigation of the effect of some production techniques and weather factors on maple sap and sugar yields in a central Michigan woodlot. Ph.D. Thesis, Mich. State Univ.

Hoffman, D.W., R.W. Wicklund and N.R. Richards. 1962. The Ontario Soil Survey. Rep. No. 29. Can. Dept. Agric. and Ont. Agric. College.

Jones, C.H., A.W. Edson, and W.J. Morse. 1903. The maple sap flow. Vt. Agric. Exp. Stn. Bull. 103: 41-184

Marvin, J.W. and M.T. Greene. 1951. Temperature-induced sap flow in excised stems of Acer. Plant Phys. 26: 565-580.

Marvin, J.W. and R.O. Erickson. 1956. A statistical evaluation of some of the factors responsible for the flow of sap from the sugar maple. Plant Phys. 31: 57-61.

Plamondon, A. 1977. Analyse préliminaire de quelques facteurs écologiques influençant la production de la sève l'Acer saccharum. Naturaliste Can. 104: 127-134.

Plamondon, A. and P.Y. Bernier. 1980. Modélisation de la coulée de l'érable à sucre (Acer saccharum Marsh.) à partir d'éléments météorologique. Can. J. For. Res. 10: 152-157.

Stevens, C.L. and R.L. Eggert. 1945. Observations of the causes of the flow of sap in red maple. Plant Phys. 20: 636-648. 